\title{
STEM Holic Community untuk Pengembangan Kompetensi Guru dalam Pembelajaran STEM
}

\author{
Hardani \\ UPTD SD Negeri Tambegan \\ hardanisaja@gmail.com
}

\section{Article History}

accepted 01/12/2020

approved 01/01/2021

published 01/03/2021

\begin{abstract}
Critical thinking skills, creative, innovative and collaborative are abilities that students must have today. STEM as an interdisciplinary approach can be used to develop these skills. To socialize STEM in learning, it is necessary to make concrete efforts to introduce it to teachers through the community at large. STEM Holic Community is a community that is committed to improving the quality of education and preparing students through developing teacher competencies with programmed STEM-based activities.
\end{abstract}

Keywords: Teacher competence, STEM

\section{Abstrak}

Keterampilan berpikir kritis, kreatif, inovatif dan kolaborasi merupakan kemampuan yang harus dimiliki peserta didik saat ini. STEM sebagai salah satu pendekatan interdisipliner dapat digunakan untuk mengembangkan keterampilan tersebut. Untuk mensosialisasikan STEM dalam pembelajaran perlu adanya upaya konkrit mengenalkannya pada guru melalui komunitas secara luas. STEM Holic Community merupakan komunitas yang mempunyai komitmen meningkatkan kualitas pendidikan dan menyiapkan peserta didik melalui pengembangkan kompetensi guru dengan kegiatan berbasis STEM yang telah diprogramkan.

Kata kunci: Kompetensi guru, STEM

Social, Humanities, and Education Studies (SHEs): Conference Series https://jurnal.uns.ac.id/shes 


\section{PENDAHULUAN}

Perubahan paradigma belajar bergeser pada upaya peningkatan keterampilan yang harus dimiliki oleh peserta didik sebagai wujud upaya penyiapan sumber daya manusia melalui pembelajaran. Pembelajaran di abad ke-21 menuntut menuntut keterampilan berpikir kritis, kreatif, inovatif dan kolaborasi. Keterampilan ini sangat dibutuhkan untuk memecahkan berbagai masalah dalam kehidupan yang semakin kompleks. (Hardani, 2020). STEM merupakan salah satu pendekatan yang dapat membekali peserta didik dapat mengembangkan kemampuan yang dibutuhkan dalam persaingan global tersebut.

Menurut pendapat Tsupros (dalam Winarni, 2016) Science, Technology, Engineering, Mathematics (STEM) merupakan pendekatan pembelajaran yang mengintegrasikan berbagai disiplin ilmu untuk digunakan dalam konteks nyata yang menghubungkan antara sekolah, dunia kerja dan dunia global. STEM menurut Vazques, Sneider, \& Comer (2013), English (2016), Sanders, (2009) Kennedy \& Odell (2014) Kelley \& Knowles (2016) Breiner et al., (2012) Jolly (2017) (dalam Padmi, 2020) menyebutkan bawah pendekatan pengajaran dan pembelajaran yang menampilkan integrasi yang berarti antara sains dan matematika pengetahuan, penerapan ilmu pengetahuan dan matematika, teknologi, dan prinsip rekayasa, merancang dan membangun solusi untuk memecahkan masalah menggunakan proses desain teknik. Dari pendapat tersebut menunjukkan proses pembelajaran menuntut peserta didik untuk bertanggungjawab atas pembelajaran yang telah dilakukan.

Dalam pengajaran dan pembelajaran pendidikan STEM, pendekatan STEM diterapkan dan disebut sebagai strategi pedagogis interdisipliner yang menekankan pada penerapan pengetahuan, keterampilan dan nilai-nilai dari disiplin ilmu, teknologi, teknik dan matematika, secara terpadu untuk membantu peserta didik memecahkan masalah dalam kehidupan nyata. Idealnya belajar di lingkungan STEM akan fokus pada pengasuhan peserta didik untuk memperoleh pengetahuan, keterampilan dan nilai-nilai dalam bidang terkait STEM. STEM akan mengembangkan angkatan kerja abad ke-21 yang sangat melek huruf dan memacu perkembangan ekonomi suatu negara. Hal ini sesuai tujuan utama pendidikan STEM bukanlah agar siswa menjadi ahli matematika, ilmuwan, teknisi, atau insinyur, meskipun akan lebih bagus jika lebih banyak anak muda kita yang memiliki aspirasi seperti itu. Tujuannya adalah agar semua siswa dapat berfungsi dan berkembang di dunia yang sangat berteknologi tinggi, yaitu menjadi melek STEM. Melek STEM sebagaimana didefinisikan oleh laporan terbaru dewan penelitian nasional yang berhasil dalam pendidikan K-12 STEM. Mengidentifikasi pendekatan yang efektif dalam sains, teknologi. (Vasques, 2013)

Prinsip panduan dalam pembelajaran STEM menurut Vasquez, Sneider, \& Comer (dalam Padmi, 2020) menekankan pada integrasi matematika dan sains, relevan bagi siswa, dapat mengembangkan keterampilan abad 21, memberikan tantangan pada siswa dan menggabungkan pembelajaran berbasis masalah dan proyek. Namun demikian, STEM sebagai pendekatan yang dianggap baru bagi sebagian guru sekolah dasar membuat mereka sulit untuk mengimplementasikanya di kelas-kelas. Kesulitan bagi guru diantaranya; (1) menentukan permasalahan dan produk hasil STEM; (2) integrasi keempat disiplin keilmuan STEM dalam proyek (Hardani, 2020). Kesulitan tersebut disebabkan kurang adanya sosialisasi secara massif tentang STEM dan kegiatan yang berhubungan dengan implementasi STEM dalam pembelajaran di kelas. Paradigma bagi guru yang masih menganggap STEM selalu robotic dan berbasis IT kadangkali menjadi kendala tersendiri. Oleh karena itu adanya kegiatan bersama bagi guru untuk mempelajari konsep dasar, implikasi teori STEM yang digunakan dalam pembelajaran melalui sebuah komunitas. 
Program Pengiriman 1000 guru yang diprogramkan pemerintah bagi guru-guru yang terpilih menjadi titik awal dalam pengembangan komunitas STEM yang dilakukan oleh penulis. Hasil seleksi yang dilakukan PPPPTK Matematika mentakdirkan dapat belajar STEM ke Seameo Recsam Penang Malaysia. Hasil kegiatan selama course, penulis implementasikan pada praktik pembelajaran dan hasilnya didesiminasikan pada INOBEL 2019. Karya inovasi tersebut diberikan apresiasi oleh Kesharlindung Dikdas menjadi pemenang ketiga kategori Guru Kelas Matematika. Dampak nyata dari proses pembelajaran yang dilaksanakan, sedikit demi sedikit merubah pemahaman bagi siswa tentang makna belajar. Selain itu hasil pembelajaran yang telah dilaksanakan, dapat mengembangkan dan menumbuhkan mental critical thinker dan problem solver, implementasi STEM dalam pembelajaran akan mengembangkan: (1) Literasi sain, teknologi, enjiniring dan matematika; (2) keterampilan Berpikir kritis, kreatif dan kolaborasi.

\section{STEM Inspiratif}

\section{HASIL DAN PEMBAHASAN}

STEM sebagai suatu pendekatan yang dapat dikatakan "baru" perlu dikenalkan secara masif agar dapat secara luas dipahami dan diimplementasikan. Ada beberapa cara yang dapat dilakukan diantaranya melalui diskusi kecil, melakukan diseminasi karya, webinar maupun workshop atau pelatihan. Di kelompok kecil, STEM dikenalkan penulis melalui diskusi pada komunitas tidak bernama bersama guru inovatif di kabupaten Bangkalan. Sebutan komunitas tidak bernama didasarkan pada tidak adanya nama pada komunitas ini. Diskusi dilakukan secara informal, baik pada saat bertemu di tempat kegiatan, di warung kopi maupun di sekolah pada saat jam luar sekolah. Diskusi sangat efektif dan bermanfaat, sehingga menginspirasi guru untuk mengimplementasikan dan mendiseminasikan di Seminar Pendidikan Matematika VII. Hasil implementasi pembelajaran dapat merubah paradigma orang tua tentang belajar. Belajar tidak hanya berorientasi pada sekedar nilai atau kemampuan kognitifnya saja, melain keterampilan pemecahan masalah yang paling penting untuk dikuasai siswa.

Masa pandemic memberikan berkah tersendiri bagi penulis untuk desiminasi secara luas. Berbagai kegiatan desiminasi dilakukan baik di daerah melalui dinas pendidikan dan yayasan Permata Hati Education Centre (PHEC), di daerah 3T bersama IGI Kabupaten Sintang, di komunitas nasional BIKE (APP) dan komunitas Literasi Menulis, KKKS di Kabupaten Sidoarjo Jawa Timur, serta menginisiasi webinar series Alumni Course bekerjasama dengan Dinas Dikpora Purworejo dan PPPPTK Matematika Yogyakarta. Selain itu di sela upaya untuk mengenalkan STEM di berbagai tempat dan komunitas, penulis juga terus melaksanakan berbagi praktik baik tentang STEM juga penulis unggah di laman guru berbagi. Unggahan ini diharapkan dapat menginspirasi guru di berbagai daerah untuk menggunakan STEM sebagai salah satu pendekatan dan pola pikir STEM dalam pembelajaran.

\section{STEM Holic Community}

Untuk lebih mengembangkan STEM lebih luas, di bulan September 2020 didirikanlah STEM-Holic Community. STEM-Holic tujuan komunitas ini sebagai wadah untuk belajar, berkarya dan menginspirasi praktik STEM khususnya di sekolah dasar. STEM-Holic merupakan wujud tanggung jawab, pengabdian dan dedikasi kami dari program 1000 guru waktu yang lalu sebagai agen perubahan. Harapan kami komunitas ini dapat menjadi salah satu ujung tombak dalam menyampaikan tentang STEM di Indonesia khususnya sekolah dasar.

STEM-Holic Community hingga saat ini telah melakukan kegiatan dalam dua angkatan. Pola kegiatan STEM-Holic yaitu in-on-in dengan materi wawasan tentang STEM, pentingnya STEM, menentukan proyek STEM, menganalisis materi yang dapat digunakan dalam STEM, menyusun lesson plan serta penilaian, praktik STEM dan 
mendokumentasikan produk karya dalam bentuk buku serta mengunggahnya pada sosial media komunitas.

Kegiatan angkatan pertama diawali dengan Ngopi Bareng Belajar STEM yang diselenggarakan secara daring dengan bekerjasama dengan Mudahsyat Blitar dengan jumlah peserta 27 orang guru dari berbagai daerah. Kegiatan STEM-Holic angkatan 2 dengan peserta 50 orang. Kegiatan saat ini dapat kami lakukan yaitu secara daring dan diskusi WA Group. Dalam setiap kegiatan STEM-Holic melibatkan pemateri dan fasilitator. Pemateri dan fasilitator kegiatan selama ini merupakan alumni kegiatan kursus STEM dari dalam maupun luar negeri. Tema yang digunakan dalam kegiatan komunitas angkatan 2 ini yaitu STEM Low Cost. Tema ini dikemukakan pertama kali pada kursus STEM yang diselenggarakan SEAQIM oleh IGA Russasmita Sri Padmi, M.Sc. Tema ini yang kami gunakan untuk mengubah paradigma tentang STEM itu sulit, robot, teknologi tinggi dan tidak dapat diterapkan di daerah terpencil sekalipun. Saat ini proses kegiatan berjalan dan akan berakhir pada bulan Desember 2020.

Beberapa permasalahan dalam mengembangkan Komunitas STEM-Holic ini, (1) pemahaman peserta tentang STEM itu rumit. Asumsi ini masih sering melekat pada peserta selama kegiatan, sehingga mereka masih ingin proyek yang digunakan untuk men-delivery materi harus berupa proyek yang sulit. Dampaknya peserta kesulitan sendiri dan tidak dapat menyelesaikan tugas sesuai dengan jadwal yang telah ditentukan; (2) Konsistensi peserta kurang. Peserta kegiatan mempunyai tujuan yang berbeda-beda. Beberapa peserta hanya ingin menambah pengetahuan tentang STEM dan mengembangkannya sendiri, ada juga peserta yang benar-benar ingin mengikuti kegiatan belajar hingga menghasilkan karya. Ini terbukti dari dua kegiatan yang dilakukan, di akhir beberapa peserta mengundurkan diri dan dikeluarkan sesuai dengan ketentuan komunitas; (3) Expert STEM kurang. Untuk mendampingi peserta dalam diskusi melalui WAG perlu fasilitator yang memahami STEM. Fasilitator tidak hanya menguasai teori STEM tetapi mereka telah mengimplementasikan dalam pembelajaran. Pengalaman fasilitator dapat digunakan untuk mendampingi peserta hingga menghasilkan karya. Selama ini komunitas STEM-Holic mempunyai fasilitator dengan jumlah yang terbatas. Keterbatasan itu tidak hanya pada jumlah, tetapi juga tentang variasi praktik STEM yang telah dilaksanakan. Untuk mengatasi permasalahan tersebut beberapa upaya yang telah dilakukan dalam implementasi program.

\section{Implementasi Program}

Implementasi program dilakukan untuk mengatasi permasalahan yang selama ini dihadapi oleh STEM-Holic Community dalam kegiatan mengembangkan STEM. Beberapa hal yang telah dilakukan yaitu: (1) melakukan pendampingan secara intens dan memberikan contoh-contoh proyek STEM Lowcost yang dapat digunakan dalam pembelajaran; (2) berkolaborasi dengan berbagai pihak untuk mendukung kegiatan komunitas; (3) Untuk mengatasi jumlah fasilitator yang expert dalam bidang STEM kami melakukan komunikasi dengan alumni pelatihan STEM dari berbagai wilayah.

Selain itu kami akan semakin intens baik secara personal maupun instansi dengan para spesialis Seaqim.

Hasil dari kegiatan pengembangan komunitas yang telah dilaksanakan oleh STEM Holic Community yaitu:

1. Mengembangkan komunitas di daerah

2. Komunitas STEM Holic Community saat ini telah ada 14 koordinator wilayah yaitu:

STEM-Holic Malang Raya, STEM-Holic Lumajang, STEM-Holic Banyuwangi, STEMHolic Cilacap, STEM-Holic Sumbawa, STEM-Holic Lombok, STEM-Holic Yogyakarta, STEM-Holic bekasi, STEM-Holic Tulungagung, STEM-Holic Bangkalan, STEM-Holic Surabaya, STEM-Holic Trenggalek, STEM-Holic Kalimantan Barat

3. Mengembangkan media publikasi 
Sebagai wujud upaya untuk memberikan wadah tentang STEM, STEM-Holic mulai membangun weblog yaitu https://www.stemholic.id dan instagram stem_holic. Keberadaan weblog ini digunakan sebagai tempat berbagi praktik belajar tentang STEM. Begitu juga dengan instagram, digunakan sebagai kegiatan mengenalkan praktik STEM yang telah dilaksanakan oleh guru-guru. Lebih lanjut media sosial lain seperti facebook akan menjadi bagian dari kegiatan sebagai media publikasi untuk mengenalkan STEM.

4. Berkolaborasi dengan berbagai pihak

Dalam upaya mendukung kegiatan yang telah dilakukan oleh STEM Holic Community yaitu berkolaborasi dengan IGI Kabupaten Sintang dan Azhra Publiser. Kolaborasi dengan IGI Kabupaten Sintang untuk pemberian apresiasi dalam bentuk sertifikat diklat. Sertifikat masih menjadi salah satu tujuan peserta dalam mengikuti setiap kegiatan, sehingga dengan apresiasi itu harapkan peserta akan lebih termotivasi. Kolaborasi dengan Azhra Publiser dalam bentuk penerbitan buku antologi. Masing-masing peserta dapat menerbitkan karya mereka dalam bentuk antologi dengan biaya yang murah, karena biaya pracetak dibebankan pada komunitas dan penerbit

\section{Program Tindak Lanjut}

Program kegiatan tindak lanjut yang akan STEM-Holic kembangkan dan lakukan yaitu:

1. Mengembangkan Komunitas

Mengembangkan STEM di 34 provinsi. STEM-Holic akan memastikan dan memetakan provinsi yang belum mempunyai perwakilan, selanjutnya menjaring peserta untuk mengikuti kegiatan di komunitas.

2. Membangun Web/Blog/Medsos

Membangun WEB kapasitas besar sebagai tempat publikasi karya dan mengintegrasikan WEB untuk keseluruhan kegiatan Komunitas

3. Berkolaborasi dengan berbagai pihak

Melanjutkan kolaborasi dengan organisasi profesi, dinas pendidikan, universitas, Lembaga yang mendukung kegiatan ini seperti SEAQIM maupun penerbit dan melakukan penjajagan untuk berkolaborasi dengan komunitas STEM di luar negeri.

4. Mengadakan Kompetisi STEM dan daerah dan nasional

Rencana dan program kegiatan lebih lanjut, STEM-Holic jika mempunyai kemampuan akan mengadakan kompetisi bagi guru dan siswa dalam praktik STEM. Namun demikian kegiatan ini perlu adanya dukungan dan kerjasama dari berbagai pihak berkaitan dengan kegiatannya. Kegiatan dapat dilakukan secara besar (nasional) maupun di daerah. Dari kegiatan ini akan banyak ide dan inovasi yang dihasilkan dari praktik pembelajaran STEM. Harapan penulis, komunitas STEM-Holic akan memberikan kontribusi yang positif bagi peningkatan mutu pendidikan di Indonesia.

\section{SIMPULAN}

Berdasar dari kegiatan STEM Holic Community dapat disimpulkan sebagai berikut:

1. STEM Holic Community merupakan sebuah komunitas guru untuk meningkatkan kompetensi guru berkaitan dengan kualitas pembelajaran melalui STEM.

2. Sebagai upaya mengembangkan komunitas di seluruh propinsi di Indonesia, STEM Holic Community menjaring melalui kegiatan pelatihan.

3. Untuk mengembangkan STEM secara luas, STEM Holic Community akan mengembangkan media publikasi yang ada.

4. Untuk memfasilitasi kegiatan, STEM Holic Community berkolaborasi dengan berbagai pihak. 
SHEs: Conference Series 4 (2) (2021) 48- 53

DAFTAR PUSTAKA

Hardani, 2020. Pembelajaran Matematika Berbasis STEM: Implementasi Variasi Pengembangan Model Pembelajaran STEM di Sekolah Dasar. Idealmathedu. 7 (2), 98-106

Padmi, IGA Russasmita Sri. 2020. STEM Activity in Primary Schools. Regular Course on STEM in Mathematics Learning for Primary School Teachers, Yogyakarta, Seaqim

Vasquez, J dan Comer M. 2013. STEM Lesson Essentials: Grade 3-8: Integrating Science, Technology, Engineering, Mathematics. United Kingdom: Heinemann.

Winarni, Zubaidah dan Koes, 2016. STEM: Apa, mengapa dan bagaimana. Prosiding Semnas Pendidikan IPA Pascasarjana UM. 1 (1):976-98 